\title{
Vascular Endothelial Growth Factor Receptor 2
}

National Cancer Institute

\section{Source}

National Cancer Institute. Vascular Endothelial Growth Factor Receptor 2. NCI

Thesaurus. Code C28496.

Vascular endothelial growth factor receptor 2 (1356 aa, 152 kDa) is encoded by the human KDR gene. This protein is involved in ligand-dependent signaling, vasculogenesis and tyrosine phosphorylation. 